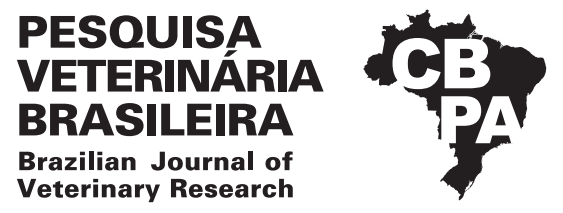

Pesq. Vet. Bras. 39(9):686-695, September 2019 DOI: 10.1590/1678-5150-PVB-6384

Original Article

ISSN 0100-736X (Print)

Livestock Diseases

ISSN 1678-5150 (Online)

\title{
Cattle diseases in Mato Grosso do Sul, Brazil: a 24-year survey (1995-2018) ${ }^{1}$
}

\author{
Rayane C. Pupin ${ }^{2 *}$ (D), Paula V. Leal ${ }^{3}$, Juliana P.L. Paula4, Carolina C. Guizelini ${ }^{4}$ (D), \\ Tessie B.M. Möck², Ricardo Antônio A. Lemos² (D) and Danilo C. Gomes² (D)
}

\begin{abstract}
Pupin R.C., Leal P.V., Paula J.P.L., Guizelini C.C., Möck T.B.M., Lemos R.A.A., \& Gomes D.C. 2019. Cattle diseases in Mato Grosso do Sul, Brazil: a 24-year survey (1995-2018). Pesquisa Veterinária Brasileira 39(9):686-695. Laboratório de Anatomia Patológica, Faculdade de Medicina Veterinária e Zootecnia, Universidade Federal de Mato Grosso do Sul, Avenida Senador Felinto Muller 2443, Vila Ipiranga, Campo Grande, MS 79074460, Brazil. E-mail: rayane.pupin@gmail.com

We reviewed the records of 5,083 cattle necropsies performed from January 1995 to December 2018 and filed at the Laboratory of Anatomic Pathology (LAP) of the "Universidade Federal de Mato Grosso do Sul" (UFMS). These necropsies were performed either by LAP-UFMS faculty $(22.33 \%)$ or by field veterinary practitioners $(77.67 \%)$ who subsequently submitted material for histological evaluation at the LAP-UFMS. Conclusive diagnoses were reached in $46.21 \%$ of the protocols (2,349 cases), and approximately $65 \%$ of the cases were classified as inflammatory or parasitic diseases, with rabies being the most diagnosed disease $(20.82 \%$ of total conclusive diagnosis). There were a large number of protocols in which the diagnosis was of nonsuppurative meningoencephalitis of unknown cause (NSMUC). Those were the main differentials for rabies and bovine herpesvirus- 5 necrotizing meningoencephalitis (NME); that is, the number of rabies cases may be even higher if one considers that many cases of NSMUC might be undiagnosed rabies cases. Toxic and toxic-infectious diseases were the second most prevalent category, and botulism cases represented $41 \%$ of this category. The other categories corresponded to less than $20 \%$ of the total diagnoses and were distributed in decreasing order of frequency as degenerative diseases $(9.79 \%)$, diseases caused by physical agents $(3.87 \%)$, other diseases $(2.13 \%)$, neoplasms and tumor-like lesions (1.79\%), metabolic or nutritional disorders $(1.75 \%)$ and congenital malformations $(0.64 \%)$. The large number of inconclusive diagnoses was mainly due to improper conditions of mailed-in material for histopathological evaluation, namely, nonrepresentative samples of all organs, autolysis, and the absence of epidemiological and clinical-pathological information.
\end{abstract}

INDEX TERMS: Cattle diseases, Mato Grosso do Sul, Brazil, survey, pathology, epidemiology, livestock, causes of death.

RESUMO.- [Doenças de bovinos em Mato Grosso do Sul, Brasil: uma pesquisa de 24 anos (1995-2018).] Em um levantamento sobre doenças de bovinos, revisamos os protocolos de 5.083 necropsias de bovinos realizadas no período de janeiro

\footnotetext{
${ }^{1}$ Received on April 17. 2019.

Accepted on April 29, 2019.

Part of the Doctoral Dissertation of the first author.

${ }^{2}$ Laboratório de Anatomia Patológica (LAP), Faculdade de Medicina Veterinária e Zootecnia (FAMEZ), Universidade Federal de Mato Grosso do Sul (UFMS), Av. Senador Felinto Muller 2443, Bairro Ipiranga, Campo Grande, MS 79074-460, Brazil. *Corresponding author: rayane.pupin@gmail.com

${ }^{3}$ Universidade Federal da Bahia (UFBA), Rua Adhemar de Barros 500, Ondina, Salvador, BA 40170-970, Brazil.

${ }^{4}$ Graduate Studies Program in Veterinary Science, Faculdade de Medicina Veterinária e Zootecnia (FAMEZ), Universidade Federal de Mato Grosso do Sul (UFMS), Av. Senador Felinto Muller 2443, Bairro Ipiranga, Campo Grande, MS 79074-460.
}

de 1995 a dezembro de 2018 e arquivados no Laboratório de Anatomia Patológica (LAP) da Universidade Federal de Mato Grosso do Sul (UFMS). Essas necropsias foram realizadas pelos veterinários e professores do LAP-UFMS $(22,33 \%)$ ou por médicos veterinários de campo $(77,67 \%)$ que, posteriormente, submeteram ao LAP-UFMS material para avaliação histológica. Diagnósticos foram conclusivos em 46,21\% dos casos protocolados (2349), e aproximadamente $65 \%$ deles foram classificados como doenças inflamatórias ou parasitárias, sendo a raiva a doença mais diagnosticada $(20,82 \%$ dos diagnósticos conclusivos). Havia um grande número de protocolos nos quais o diagnóstico era de encefalite/meningoencefalite não supurativa de causa indeterminada, para o qual os dois principais diferenciais são raiva e meningoencefalite necrosante por herpesvírus bovino; isso sugere que o número de casos de raiva pode ser ainda maior, se considerarmos que 
muitos destes podem ser casos de raiva não diagnosticados adequadamente. As doenças tóxicas e toxi-infecciosas foram a segunda categoria mais prevalente; dentre elas, os casos de botulismo compuseram $41 \%$. As demais categorias corresponderam a menos de $20 \%$ do total de diagnósticos e foram distribuídas em ordem decrescente de frequência, em doenças degenerativas $(9,79 \%)$, doenças causadas por agentes físicos $(3,87 \%)$, outras doenças $(2,13 \%)$, neoplasmas e lesões tumoriformes $(1,79 \%)$, distúrbios metabólicos ou nutricionais $(1,75 \%)$ e malformações congênitas $(0,64 \%)$. 0 grande número de diagnósticos inconclusivos deveu-se principalmente às condições inadequadas do material enviado ao LAP-FAMEZ para avaliação histopatológica, ou seja, amostras não representativas de todos os órgãos, autolisadas ou acompanhadas de poucas de informações epidemiológicas e clínico-patológicas.

TERMOS DE INDEXAÇÃO: Doenças de bovinos, Mato Grosso do Sul, Brasil, estudo retrospectivo, bovinos, levantamento, patologia, epidemiologia, causas de morte.

\section{INTRODUCTION}

The meat industry is an essential segment of the Brazilian economy, and beef is one of the main export products in the country. Any factor that may restrict trade in livestock products will result in a critical economic loss (Schulz et al. 2018). To maintain agribusiness, it is essential to maintain the health status of cattle herds. Thus, understanding which diseases affect cattle and their presentation and prevalence is paramount (Lucena et al. 2010).

Knowledge about the prevalence of different diseases that affect the cattle herds in a region is fundamental; with this knowledge, field practitioners and veterinarians can select from a list of differential diagnoses when reading laboratory or anatomopathological reports (Lucena et al. 2010).

Although there are few variations in diseases within the areas covered by each diagnostic laboratory (Rissi et al. 2010), epidemiological characteristics can vary widely between regions. There are also differences in the causes of mortality between regions due to different breeding systems (Mello et al. 2017, Rondelli et al. 2017, Santos et al. 2018).

Although some studies have investigated bovine diseases diagnosed in Mato Grosso do Sul (MS) (Salvador et al. 1998, Nakazato et al. 2000, Paiva et al. 2000, Brum et al. 2002, Lemos et al. 2005, Carvalho et al. 2006, Ferreira et al. 2008, Santos et al. 2012, Carvalho et al. 2013, Pinto et al. 2013, Ribas et al. 2013, Bacha et al. 2014, Carvalho et al. 2014, Souza et al. 2015, Faccin et al. 2016, Heckler et al. 2018, Guizelini et al. 2019, Pupin et al. 2019), there are no comprehensive data on the primary diseases that affect cattle in this region. We aimed to determine the frequency and epidemiological aspects of the primary bovine diseases diagnosed in MS by undertaking a retrospective study of 24 years (1995-2018).

\section{MATERIALS AND METHODS}

The records of cattle necropsies evaluated at the Laboratory of Anatomic Pathology (LAP) of the "Faculdade de Medicina Veterinária e Zootecnia" (FAMEZ) at the "Universidade Federal de Mato Grosso do Sul" (UFMS) from January 1995 to December 2018 were reviewed.
The exclusion criteria for the survey were as follows: (i) records on material from healthy cattle that were referred to the LAP-FAMEZ by the Ministry of Agriculture, Livestock and Supply from 2001 to 2007 during the Bovine Spongiform Encephalopathy surveillance program, (ii) material from experiments, (iii) material from states other than MS, (iv) samples with a diagnosis not associated with the animal's death, and (v) samples collected from a slaughterhouse.

Diagnoses were considered inconclusive when the case lacked gross and/or microscopic features that could explain the clinical signs and death or lacked characteristic clinical signs that could confirm the diagnosis even in the absence of anatomical lesions, as is the case of botulism and tetanus. The instances with conclusive diagnoses were grouped as previously described (Rondelli et al. 2017): inflammatory and parasitic diseases; toxic and toxic-infectious diseases; diseases caused by physical agents, metabolic or nutritional disorders, degenerative processes, congenital malformations, neoplasms and tumor-like lesions; and miscellaneous.

Botulism was diagnosed based on clinical signs, epidemiological findings and the absence of macroscopic and microscopic lesions in cases in which the necropsy was performed by the laboratory staff. Additionally, the detection of botulin toxin in the animal or in another animal from the same outbreak was considered a diagnostic criterion. The most frequently diagnosed diseases were individually discussed.

\section{RESULTS}

From January 1995 to December 2018, 5,083 bovine samples from necropsies performed by veterinarians of the LAP-FAMEZ staff or by field veterinary practitioners were evaluated; 1,135 (22.33\%) were performed by LAP-UFMS faculty and 3,948 (77.67\%) by field veterinary practitioners who subsequently submitted material to the LAP-UFMS for histological evaluation. Out of 2,734 necropsies (53,79\%) with an inconclusive diagnosis, 2,459 (89.94\%) were performed by field veterinary practitioners and 275 (11.06\%) by LAP-FAMEZ faculty. Conclusive diagnoses were obtained in $46.21 \%$ of the cases $(2,349$ necropsies). The stratification of the disease categories is shown in Figure 1.

The main cause of deaths was inflammatory and parasitic diseases representing more than $65 \%$ of the conclusive diagnoses (Table 1). The group with the second highest number of diagnoses was toxic diseases and toxic-infectious diseases, corresponding to 356 diagnoses (Table 2). Mortalities caused by physical agents are shown in Table 3 . Those produced by metabolic or nutritional disorders are shown in Table 4, and congenital malformations in Table 5 . There were 42 cases of neoplasms and tumor-like lesions found at necropsy (Table 6). Diseases that could not be included in any of the categories were classified as "miscellaneous" and are listed in Table 7.

\section{DISCUSSION}

In this 24-year study, we observed that over time, the number of necropsies performed gradually decreased, as has also been observed in similar surveys (Oliveira et al. 2012), although the cause of this decrease is unknown. This decrease suggests that although necropsy is often the only method of diagnosis, it is often neglected (Peixoto \& Barros 1998). Usually, financial concerns prevent producers from seeking help. The request for necropsy is most frequent when (i) death occurs in cattle of high commercial value; (ii) the 


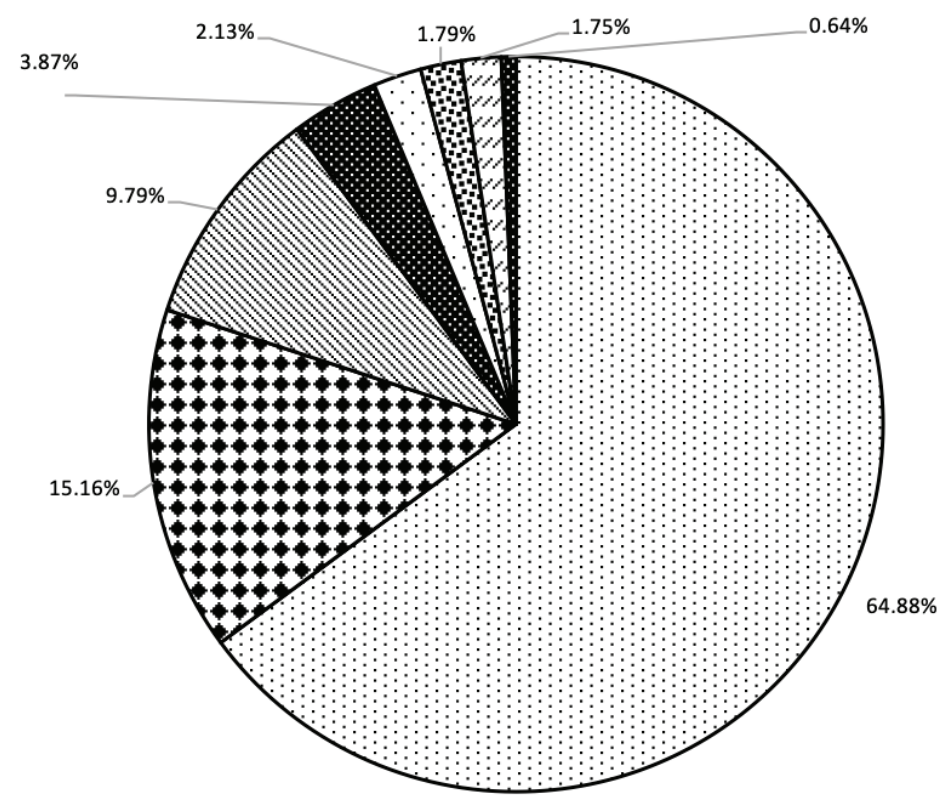

口Inflammatory and parasitic diseases (1524)

هToxic and toxic-infectious diseases (356)

ه Degenerative diseases (230)

Caused by physical agents (91)

口Miscellaneous diseases (50)

DNeoplasms and tumor-like lesions (42)

口Metabolic/nutritional disorders (41)

a Congenital malformations (15)

Fig.1. Necropsies performed in cattle from 1995 to 2018 in Mato Grosso do Sul, and number of cases of each category.

Table 1. Inflammatory and parasitic diseases $(n=1,524)$ in cattle in Mato Grosso do Sul (January 1995-December 2018)

\begin{tabular}{|c|c|c|c|c|c|}
\hline Disease & $\mathrm{N}^{\mathrm{a}}$ & $\%$ & Disease & $\mathrm{N}^{\mathrm{a}}$ & $\%$ \\
\hline Rabies & 489 & 32.09 & Myocarditis (unknown cause) & 3 & 0.2 \\
\hline $\begin{array}{l}\text { Non-suppurative meningoencephalitis } \\
\text { (unknown cause) }\end{array}$ & 319 & 20.93 & Endocarditis & 3 & 0.2 \\
\hline Septicemia & 85 & 5.58 & Leptospirosis & 3 & 0.2 \\
\hline Tick fever & 84 & 5.51 & Pericarditis & 3 & 0.2 \\
\hline Blackleg & 57 & 3.74 & Pleuritis + pericarditis & 3 & 0.2 \\
\hline Other pneumonia & 31 & 2.03 & $\begin{array}{l}\text { Anemia and hypoproteinemia (Rhipicephalus } \\
\text { microplus) }\end{array}$ & 2 & 0.13 \\
\hline Peritonitis & 24 & 1.57 & Bovine viral diarrhea & 2 & 0.13 \\
\hline Osteomyelitis & 21 & 1.38 & Mastitis & 2 & 0.13 \\
\hline Cerebral babesiosis & 21 & 1.38 & Mycotic pneumonia & 2 & 0.13 \\
\hline Hemonchosis & 12 & 0.79 & Malignant edema & 1 & 0.07 \\
\hline Bacterial meningoencephalitis & 10 & 0.66 & Generalized mycotic infection & 1 & 0.07 \\
\hline Enteric colibacillosis & 9 & 0.59 & Meningoencephalitis (Histophilus somni) & 1 & 0.07 \\
\hline Cystitis & 8 & 0.52 & $\begin{array}{l}\text { Meningoencephalitis with mixed inflammatory } \\
\text { infiltrate }\end{array}$ & 1 & 0.07 \\
\hline Hepatic abscesses & 7 & 0.46 & Septic necrotizing myositis & 1 & 0.07 \\
\hline Eimeriosis & 5 & 0.33 & Septic osteomalacia & 1 & 0.07 \\
\hline Estomatitis/esophagitis (unknown cause) & 5 & 0.33 & Suppurative otitis & 1 & 0.07 \\
\hline Pituitary abscess & 5 & 0.33 & Parasitism (Trichostrongylus sp.) & 1 & 0.07 \\
\hline Tuberculosis & 5 & 0.33 & Pyelonephritis and urethritis & 1 & 0.07 \\
\hline Dermatophilosis & 4 & 0.26 & Pneumonia BRSV & 1 & 0.07 \\
\hline
\end{tabular}

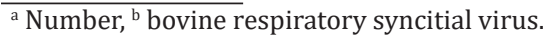


number of fatalities is abnormally high; (iii) there are livestock insurance investigations; or (iv) there is a judicial dispute (Waldner et al. 2009). From the perspective of farmers, it is easier and cheaper to send fragments of viscera and/or samples for clinical analysis than to transport a cadaver to the lab (Watson et al. 2008). Transportation from the property to the laboratory is a challenge, as it frequently requires travel over long distances. Surveys from Sweden (Svensson et al. 2006) and the United Kingdom (Watson et al. 2008) conclude

Table 2. Toxic and toxic-infectious diseases (356) in cattle diagnosed in LAP-UFMS (January 1995-December 2018)

\begin{tabular}{lcc}
\hline \multicolumn{1}{c}{ Disease } & $\begin{array}{c}\text { Number } \\
\text { of cases }\end{array}$ & $\%$ \\
\hline Botulism & 146 & 46.01 \\
Poisoning by Vernonia sp. & 53 & 14.89 \\
Poisoning by Senna sp. & 28 & 7.87 \\
Toxic hepatic fibrosis & 23 & 6.46 \\
Poisoning by Brachiaria sp. & 19 & 5.34 \\
Tetanus & 15 & 4.21 \\
Poisoning by Amorimia sp. & 11 & 3.09 \\
Toxic nephrosis associated with crystals & 10 & 2.81 \\
(unknown cause) & & \\
Toxic nephrosis (unknown cause) & 8 & 2.25 \\
Photosensitization (unknown cause) & 6 & 1.69 \\
Poisoning by Enterolobium contortisiliquum & 6 & 1.69 \\
Poisoning by citrus pulp & 5 & 1.4 \\
Poisoning by salt (NaCl) & 4 & 1.12 \\
Lead poisoning & 4 & 1.12 \\
Poisoning by Stryphnodendron fissuratum & 4 & 1.12 \\
Urea poisoning & 3 & 0.84 \\
Poisoning by abactin & 3 & 0.84 \\
Poisoning by amitraz & 2 & 0.56 \\
Poisoning by cassava (Manihot esculenta) & 2 & 0.56 \\
Poisoning by Solanum malacoxylon & 2 & 0.56 \\
Poisoning by Crotalaria sp. & 1 & 0.28 \\
Poisoning by terramycin & 1 & 0.28 \\
& &
\end{tabular}

Table 3. Diseases caused by physical agents $(n=91)$ in cattle in Mato Grosso do Sul (January 1995- December 2018)

\begin{tabular}{lcc}
\hline \multicolumn{1}{c}{ Disease } & $\begin{array}{c}\text { Number } \\
\text { of cases }\end{array}$ & $\%$ \\
\hline Hypothermia & 35 & 35.4 \\
Fracture & 14 & 14.1 \\
Trauma & 14 & 14.1 \\
Aspiration pneumonia & 14 & 14.1 \\
Hardware disease & 3 & 3.03 \\
Water deprivation & 2 & 2.02 \\
Diphteric rumenitis due to ingestion of caustic & 2 & 2.02 \\
chemical & & \\
Abomasal obstruction & 2 & 2.02 \\
Spinal cord compression by bone overgrowth & 1 & 1.01 \\
Milk-induced necrotic rumenitis & 1 & 1.01 \\
Traumatic rumenitis & 1 & 1.01 \\
Sand impaction & 1 & 1.01 \\
Electrocution (presumptive) & 1 & 1.01 \\
\end{tabular}

Table 4. Metabolic and nutritional disorders in cattle in Mato Grosso do Sul (January 1995-December 2018); percent over 41 cases $(n=41)$

\begin{tabular}{lcc}
\hline \multicolumn{1}{c}{ Disease } & $\begin{array}{c}\text { Number } \\
\text { of cases }\end{array}$ & $\%$ \\
\hline Ruminal acidosis & 10 & 24.39 \\
Cobalt deficiency (presumptive) & 7 & 17.07 \\
Starvation & 6 & 14.63 \\
Ketosis & 6 & 14.63 \\
Hypocalcemia post-partum & 3 & 7.32 \\
Vagal indigestion & 3 & 7.32 \\
Bloat & 3 & 7.32 \\
Osteomalacia & 1 & 2.44 \\
Vitamine E and selenium deficiency & 1 & 2.44 \\
Urethral obstruction (urolithiasis) & 1 & 2.44
\end{tabular}

Table 5. Congenital malformations $(n=15)$ in cattle in Mato Grosso do Sul (January 1995-December 2018)

\begin{tabular}{lcc}
\hline \multicolumn{1}{c}{ Disease } & $\begin{array}{c}\text { Number } \\
\text { of cases }\end{array}$ & $\%$ \\
\hline Arthrogryposis & 3 & 20 \\
Patent urachus & 2 & 13.33 \\
Multiple malformations & 2 & 13.33 \\
Anal atresia & 1 & 6.67 \\
Multiple cardiac defects & 1 & 6.67 \\
Umbilical hernia & 1 & 6.67 \\
Vaginal malformations & 1 & 6.67 \\
Forelimbs malformations & 1 & 6.67 \\
Palatoschisis (cleft palate) & 1 & 6.67 \\
Patent ductus arteriosus & 1 & 6.67 \\
Persistent right aortic arch & 1 & 6.67
\end{tabular}

Table 6. Neoplasms and tumor-like lesions $(n=42)$ in cattle in Mato Grosso do Sul (January 1995-December 2018)

\begin{tabular}{lcc}
\hline \multicolumn{1}{c}{ Type of lesion } & $\begin{array}{c}\text { Number } \\
\text { of cases }\end{array}$ & $\%$ \\
\hline Bovine enzootic leukosis & 9 & 21.43 \\
Lymphoma & 6 & 14.29 \\
Squamous cell carcinoma & 6 & 14.29 \\
Hepatocellular carcinoma & 3 & 7.14 \\
Disseminated anaplastic carcinoma & 2 & 4.76 \\
Renal carcinoma & 2 & 4.76 \\
Cholangiocellular carcinoma & 2 & 4.76 \\
Fibrosarcoma & 1 & 2.38 \\
Mesothelioma & 1 & 2.38 \\
Undifferentiated pulmonary carcinoma & 1 & 2.38 \\
Esophagic fibromas & 1 & 2.38 \\
Liposarcoma & 1 & 2.38 \\
Meningioma & 1 & 2.38 \\
Metastatic pheocromocytoma (lung) & 1 & 2.38 \\
Metastatic seminoma (disseminated) & 1 & 2.38 \\
Olfactory neuroblastoma (presumptive) & 1 & 2.38 \\
Choroid plexus papilloma & 1 & 2.38 \\
Embryomal rhabdomyosarcoma & 1 & 2.38 \\
Undifferentiated sarcoma & 1 & 2.38
\end{tabular}


Table 7. Miscellaneous diseases $(n=50)$ in cattle diagnosed at LAP-UFMS (January 1995-December 2018)

\begin{tabular}{lcc}
\hline \multicolumn{1}{c}{ Disease } & $\begin{array}{c}\text { Number } \\
\text { of cases }\end{array}$ & $\%$ \\
\hline Acute hepatic necrosis (unknown cause) & 14 & 28 \\
Heart failure & 10 & 20 \\
Muscle rupture & 4 & 8 \\
Hypovolemic shock & 4 & 8 \\
Abomasal ulcer & 2 & 4 \\
Snake bite & 2 & 4 \\
Amiloidosis & 1 & 2 \\
Omasal impactation & 1 & 2 \\
Evisceration and intestinal perforation & 1 & 2 \\
Pulmonary hemorrhage & 1 & 2 \\
Hypomyelinogenesis & 1 & 2 \\
Chronic renal failure & 1 & 2 \\
Intussusception & 1 & 2 \\
Abomasal glandular hyperplasia and metaplasia & 1 & 2 \\
Necrosis of cerebral white matter (unknown cause) & 1 & 2 \\
Megaesophagus & 1 & 2 \\
Senility & 1 & 2 \\
Vena cava symdrome & 1 & 2 \\
Abomasal torsion & 1 & 2 \\
Intestinal torsion & 1 & 2 \\
& & 2 \\
\hline
\end{tabular}

that this is the leading reason reported by producers for not sending animals to necropsy at the laboratory.

The percentage of inconclusive cases was higher than that (14.2-37.1\%) in similar surveys from Rio Grande do Sul, southern Brazil (Lucena et al. 2010, Schild et al. 2013, Mello et al. 2017), but similar to that observed in the neighboring state of Mato Grosso (Rondelli et al. 2017). In the current study, almost $90 \%$ of the necropsies were performed by field veterinary practitioners, and tissue samples were sent to LAP-FAMEZ. These samples were often suboptimal for histopathological evaluation because (i) there were no representative samples of all organs associated with the disease, (ii) tissues were autolyzed, and (iii) there was lack of epidemiological and clinical-pathological information. This might explain the relatively high number of inconclusive diagnoses in mailed-in cases compared with cases worked up by the LAP-FAMEZ staff. Similar discrepancies have been reported by others (Lemos et al. 2005, Lucena et al. 2010, Rissi et al. 2010, Ribas et al. 2013, Rondelli et al. 2017).

Similarly to what is described in Mato Grosso (Rondelli et al. 2017), in our study, the five most common diagnosis (rabies, NSMUC, polioencephalomalacia, meningoencephalitis caused by BoHV and botulism) are characterized by neurological signs. This aspect can suggest some hypothesis: (i) because of the great importance of rabies in MS, when people see a bovine with neurological signs, they normally suspects of rabies and tend to send the animal to necropsy or do the procedure to collect samples to send to a diagnostic laboratory; (ii) normally, these animals have a clinical course of some days, so it's possible to see the evolution of the disease and decide about do or not the necropsy or (iii) these diseases are really the main cause of cattle death in the state.
Inflammatory and parasitic diseases were the leading causes of death of cattle in the present study, similar to results reported by other surveys all over the country (Lucena et al. 2010, Assis-Brasil et al. 2013, Mello et al. 2017, Rondelli et al. 2017).

Rabies was the most frequently diagnosed disease. This confirms data from other states in Brazil that indicate rabies as a critical problem nationwide (Galiza et al. 2010, Rondelli et al. 2017, Terra et al. 2018). Rabies corresponded to $9.62 \%$ of cattle diseases in the current study; this value is $20.82 \%$ when only conclusive diagnoses are considered and represents $32.09 \%$ of all inflammatory and parasitic infections. This number is much higher than that described in studies conducted in southern Brazil, where rabies corresponds to 4.67\% (Lucena et al. 2010) and 3.67\% (Schild et al. 2013) of cases with a conclusive diagnosis. Rabies morbidity rates were $0.008 \%-64 \%$. The number of rabies diagnoses is potentially even higher in the present study since the second most frequent diagnosis $(n=319)$ of inflammatory and parasitic diseases is nonsuppurative meningoencephalitis of unknown cause (NSMUC), which could be cryptic cases of rabies. Another differential would be necrotizing meningoencephalitis (NME) by bovine herpesvirus (BoHV) (Rondelli et al. 2017). However, rabies lacks the severe cerebrocortical necrosis found in BoHV-induced disease (Rissi et al. 2007, 2010).

Among the diagnoses of NSMUC, 295 (92.48\%) were made on mailed-in bovine tissues. This negatively influences the number of confirmed diagnoses because fragments from the brain, cerebellum and spinal cord were sent in only 37 cases of NSMUC. The nonreferral of the entire central nervous system (CNS), mainly portions of the spinal cord, for evaluation reduces the chances of diagnosing rabies, as the lesion distribution and amount of antigen vary between CNS sites but are consistently present in the spinal cord (Bingham \& Van der Merwe 2002, Bassuino et al. 2016). The submission of fragments from spinal cord, cerebellum, and brainstem, especially from livestock that have been euthanized, is critical for diagnosis since there is a high risk of false negatives when only the cerebral hemispheres are evaluated (Lemos 2005). In addition, sending the GRH complex (trigeminal ganglion, rete mirabile and hypophysis) improves diagnosis accuracy since more than $78 \%$ of rabid cattle have lymphoplasmacytic ganglioneuritis with or without inclusion bodies (Lemos et al. 2005, Rech et al. 2006, Marcolongo-Pereira et al. 2011). Accordingly, the number of diagnoses of NSMUC decreased beginning in 2004, probably in association with the publication of the manual on procedures for the diagnosis of bovine CNS diseases (Barros \& Figueiredo 2003) by the Ministry of Agriculture, Livestock and Supply.

A previous survey involving CNS diseases of cattle in MS (Ribas et al. 2013) suggested the existence of cyclicity in the occurrence of rabies. However, in the current study, there was a gradual increase in the number of diagnoses between 1995 and 2002, which was paralleled by an increase in the number of bovine samples evaluated. This was followed by a decrease, with small oscillations in subsequent years, until 2018 (Fig.2). Similar to what was described in a survey in Paraná, southern Brazil (Dognani et al. 2016), the occurrence of rabies in our study varied from year to year, but the existence of cyclicity was questionable and in that study (Dognani et al. 2016) was considered to be 18 years, however, the authors 


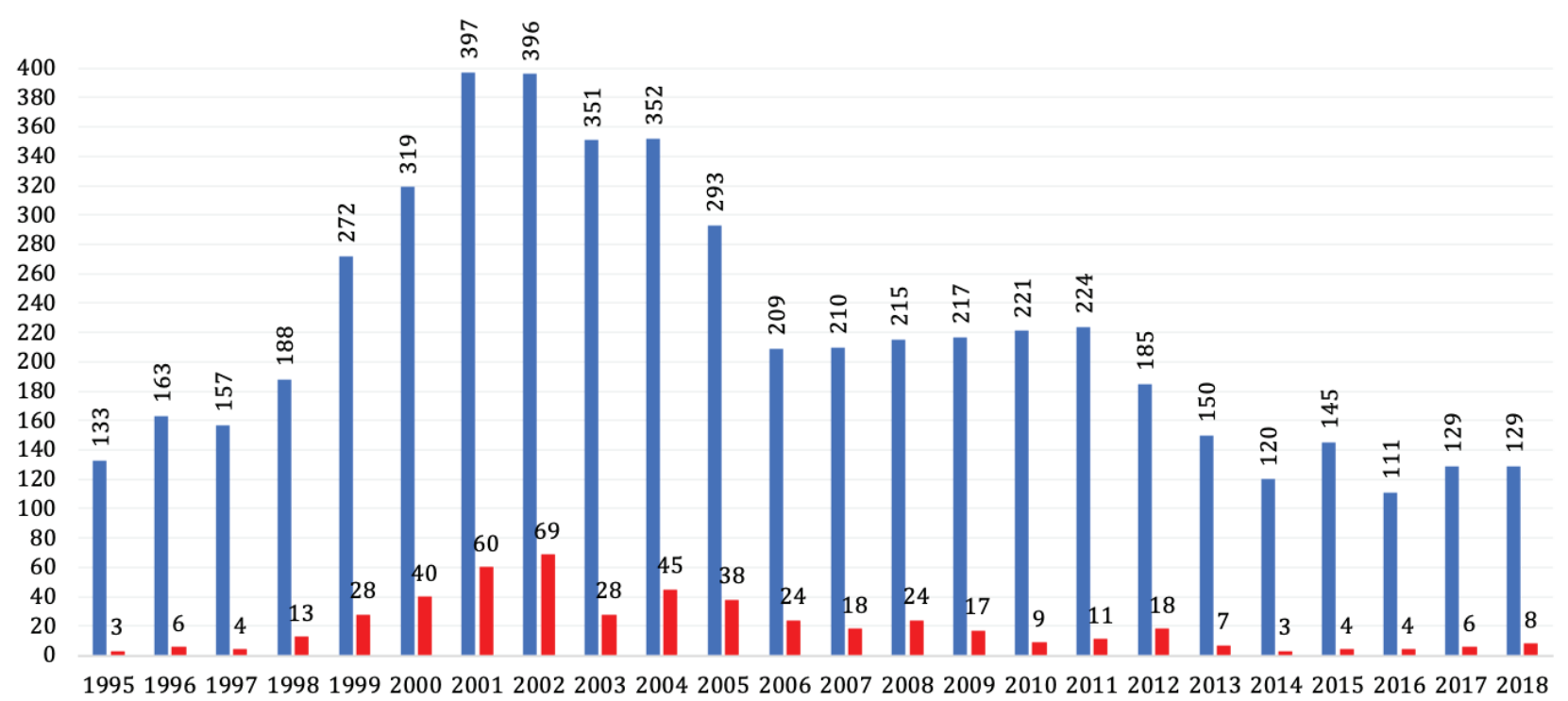

Fig.2. Total number of necropsies in cattle (blue bar) and number of cases of bovine rabies (red bar) in Mato Grosso do Sul from 1995 to 2008.

did not back up this assertion of cyclicity with hard data. In our study, it was not possible to verify cyclicity in rabies occurrence because the number of cases diagnosed does not reflect its actual occurrence due to underreporting of cases and the fact that we considered only the materials referred for histopathological evaluation. The number of cattle deaths from rabies reported in our study is smaller than that determined by other research performed at our laboratory because unlike in previous research (Mello et al. 2019), our data do not include all cases of cattle rabies worked up by the official sanitary defense laboratory from MS.

The age of rabid cattle in the current survey varied from 30 days to 16 years. The highest number of cases (35.99\%) occurred in calves aged up to one year, followed by cattle aged 13 to 24 months (26.17\%). A similar age distribution was reported from the state of Paraíba (Lima et al. 2005). These authors attributed the highest occurrence of cases in young cattle to the weak immunity of this age group, which may be due to lack of booster doses at 30-40 days after an earlier (prime) dose or to a delay in prime vaccination, which should be performed between the third and fourth months of life.

NME by BoHV (147 cases) was the second most common inflammatory disease. More than $70 \%$ of individuals (104 cases) affected by NME were 12- to 24-month-old cattle. NME by BoHV-5 is typically described in the literature as a disease of young calves (Colodel et al. 2002, Elias et al. 2004, Halfen \& Riet-Correa 2007, Galiza et al. 2010, Cagnini et al. 2017, Middleton 2017, Blume et al. 2018); however, some reports indicate that the disease can occur in adult cattle (Roels et al. 2000 , Rissi \& Barros 2013). Morbidity was up to $11 \%$. Stress factors that could have induced viral reactivation (Halfen \& Riet-Correa 2007), such as weaning, castration, vaccination, deworming, pasture change, feed change and transportation (Rissi et al.2010, Santos et al. 2018), were not mentioned in most protocols. In cases where this information was available, the main stress factor mentioned was transportation and mixing of large numbers of calves (13 cases). Finally, one should consider that at least some cases of NME by BoHV were associated with recent viral infection and not with reactivation of previous infection (Lemos 2005).
Cases of meningoencephalitis caused by BoHV have often been attributed to BoHV-5 (Rissi et al. 2007) because this is the type most commonly associated with neurological diseases. However, meningoencephalitis caused by BoHV-1 was already described (Roels et al. 2000, Rissi et al. 2008) and cases were also experimentally reproduced by this herpesvirus type (Marin et al. 2015). So, as in our study we didn't do the characterization of the agent in the cases diagnosed, it was considered just herpetic meningoencephalitis.

The typical gross brain lesions for NME by BoHV described in the literature as flattening and yellow discoloration of the cerebral gyri and softening of the cerebral cortex (Elias et al. 2004, Rissi et al. 2010, Rissi \& Barros 2013, Blume et al. 2018 ) were reported in only $41 \%$ of our cases. Again, we interpreted this as due to unreported gross findings, since no gross description of the brain was provided in 50 cases. Very acute lesions may be easily neglected when necropsy is performed by a nonpathologist veterinarian (Rissi et al. 2007); furthermore, since the brain is softened, collection artifacts are prone to occur and can be interpreted as nonlesions.

There were 85 cases (3.62\% of conclusive cases) of septicemia. Septicemia was most frequently diagnosed in young calves. Seventy-nine (93\%) of the individuals in the septicemic category were calves less than 12 months old. Forty-four were calves up to 30 days old, 28 were calves between 31 and 180 days old, and five were calves between six and 12 months old. Only five adult cattle were affected; in two individuals, it was possible to identify the source of the primary infection: one dairy cow had severe mastitis, and the Nellore heifer developed postpartum metritis and subsequent septicemia.

Results of bacteriological culture were present in 12 of the 85 reports. The following bacteria were identified: Escherichia coli (in 5 cases), Pseudomonas sp. (3 cases), Streptococcus sp. (1 case), Corynebacterium sp. (1 case), Acinetobacter sp. (1 case) and Trueperella pyogenes ( 1 case). Despite the low number of tests performed, the results are similar to those described in the literature, which mention gram-negative bacteria, especially E. coli, as the most common pathogens associated with bacterial septicemia in calves (Fecteau \& George 2004, 
Dore \& Smith 2017). When outbreaks of sepsis and meningitis are diagnosed on a farm, risk factors or management issues must be investigated. The most common are contaminated colostrum, improper navel asepsis, overcrowding, and poor hygiene (Dore \& Smith 2017).

Tick fever was the seventh most frequent disease $3.58 \%$ of bovine deaths). This number is lower than that observed southern Rio Grande do Sul, southern Brazil (Almeida et al. 2006), which is expected since midwestern Brazil is characterized by enzootic stability and southern Brazil by enzootic instability (Farias 2007). The animals ranged in age from two days to 11 years old, and most were zebuine cattle, probably because of the high number of zebuine cattle raised in MS due to the lack of a susceptibility difference between zebuine and taurine cattle (Jonsson et al. 2008). Epidemiological, clinical and pathological aspects of bovine babesiosis diagnosed in MS have already been published (Pupin et al. 2019).

In the group of toxic and toxic-infectious diseases, 146 (41.01\%) were cases of botulism. The diagnoses were made in a similar way as in other states in Brazil (Galiza et al. 2010, Schild et al. 2013, Rondelli et al. 2017, Terra et al. 2018). The other diagnostic criterion - detection of botulin toxin was not described in previous surveys (Galiza et al. 2010, Schild et al. 2013, Rondelli et al. 2017, Terra et al. 2018) but was used in one recent outbreak in MS (Guizelini et al. 2019). Similarly, in MT (Rondelli et al. 2017), botulism was the main toxic disease diagnosed; the opposite was observed in Rio Grande do Sul, southern Brazil, where poisoning by plants was the main toxic cause of bovine death (Lucena et al. 2010, Schild et al. 2013, Santos et al. 2019). Morbidity ranged from 0.08 to $64.7 \%$.

The cases occurred in small or large outbreaks affecting from 14-1,100 cattle. We followed the course of 11 outbreaks. Samples of 50 cattle were analyzed. Two of those outbreaks occurred in feedlots - one associated with the feeding of moldy hay (Soares et al. 2018a) and the other of contaminated rehydrated corn (Guizelini et al. 2019). The other nine were observed in extensively raised cattle at pasture. Seven of those nine were associated with osteophagia, and two with drinking from a contaminated pond. The number of cattle affected in the other outbreaks was 2-20. Because samples from only one bovine per occurrence were evaluated, these cases were not listed as outbreaks. Most of the cases occurred in cattle raised at pasture in farms where carrion was left in the pastures (Lemos 2005, Rondelli et al. 2017). This reinforces the notion that most cases of botulism in cattle at pasture are related to osteophagia, in contrast to observations in northeastern Brazil (Galiza et al. 2010), where outbreaks occur primarily in cattle fed chicken litter.

Poisoning by Vernonia sp. was the main plant poisoning diagnosed and represented $2.26 \%$ of all diagnoses and was the main toxic disease associated with plant poisoning. Of these cases, 29 were already published (Brum et al. 2002). The remaining cases occurred in cattle over one year old and in seven farms in the form of large outbreaks affecting 17-200 cattle. Epidemiological data and information on the economic impact caused by this type of plant poisoning are available (Soares et al. 2018b).

Degenerative diseases were the third most frequent group. In this category, only two disorders were diagnosed: polioencephalomalacia (PEM) (205 cases) and muscular necrosis of unknown cause (25 cases).
PEM was the central degenerative disease, as is typically described in other regions of Brazil (Lucena et al. 2010, Rondelli et al. 2017). It represented more than $89 \%$ of the cases in this disease category and was the third most prevalent diagnosis of all cattle diseases, corresponding to $8.73 \%$ of the conclusive diagnoses, a number well above that described in southern Rio Grande do Sul (Lucena et al. 2010, Schild et al. 2013). This suggests that some environmental aspects present in Midwestern Brazil might favor the development of the disease. Morbidity was generally low (0.016-23\%). PEM is reported as a common problem in feedlot calves between six and 18 months of age in the USA (Dore \& Smith 2017). In the present study, the majority of PEM cases involved cattle at pasture aged between 13 and 36 months (62\%). The etiology was not determined in any case of PEM, as is usually the case (Lemos 2005, Rissi et al. 2010, Rondelli et al. 2017, Terra et al. 2018). However, approximately $70 \%$ of the necropsy records did not contain any epidemiological information, which definitively and profoundly compromised the identification of possible agents involved.

Death of cattle due to hypothermia (35 cases) corresponded to the most frequent disease in the category of diseases caused by a physical agent, accounting for $38.46 \%$ of cases. The vast majority of instances (33 cases) occurred in the period of 2000-2010 and has been previously described (Santos et al. 2012). There were an additional two outbreaks of this condition on a farm in which, of a total of 500 cattle, 40 became ill, and 30 died. A sudden drop in temperature the day before the deaths and the clinical signs and pathological findings were similar to those in previously published cases (Santos et al. 2012).

The number of neoplasms and tumor-like lesions is much lower than that described in other Brazilian surveys (Lucena et al. 2010, 2011, Reis et al. 2017). We attribute this discrepancy to a large number of cases of chronic bracken fern (Pteridium aquilinum) intoxication in cattle in the south, which is known to induce various types of tumors in the urinary bladder and squamous cell carcinoma in the upper alimentary tract (Lucena et al. 2010), and to the high incidence of lymphomas associated with infection with the retrovirus of bovine enzootic leukosis (Reis et al. 2017). In addition, more than $90 \%$ of the samples evaluated in those surveys (Lucena et al. 2010, 2011) were from dairy cattle that remained in the herd longer (reaching the "tumor age") than did beef cattle. In another survey in southern Brazil involving only dairy cows (Mello et al. 2017), neoplasia was the second most frequent cause of death, with lymphoma as the leading neoplasm.

The remaining category had a low number of cases. We believe that the economic losses resulting from these cases were not significant since these cases are infrequent in cattle (Lucena et al. 2010, Rondelli et al. 2017). Nutritional and metabolic disorders corresponded to a small proportion of the diagnoses possibly because most animals were beef cattle raised in an extensive system at pasture.

\section{CONCLUSIONS}

The main causes of bovine death in Mato Grosso do Sul, Central-Western Brazil, identified in 24 years were inflammatory and parasitic diseases, toxic diseases and degenerative diseases.

The main diagnose was rabies, followed by nonsuppurative meningoencephalitis of unknown cause, polioencephalomalacia, 
necrotizing meningoencephalitis by bovine herpesvirus and botulism, all diseases that causes neurological signs.

We observed a decrease in the number of samples from bovine's necropsies evaluated over the years, but we couldn't suggest possible reasons for it.

Deaths caused by physical agents, metabolic and nutritional disorders and neoplasms and tumor-like lesions represented a low percentage of the cases. This is related to cattle production system in MS, which is predominantly in pastures and for beef purposes.

The large number of inconclusive diagnoses is associated with failure to collect data and samples, which reinforces the vulnerability of the diagnosis process.

Acknowledgements.- The authors would like to thank all the laboratory staff members. This study was partially funded by the "Coordenação de Aperfeiçoamento de Pessoal de Nível Superior" (CAPES), Brazil, Finance code 001.

Conflict of interest statement.- The authors have no competing interests.

\section{REFERENCES}

Almeida M.B.D., Tortelli F.P., Riet-Correa B., Ferreira J.L.M., Soares M.P., Farias N.A.R., Riet-Correa F. \& Schild A.L. 2006. Tristeza parasitária bovina na região sul do Rio Grande do Sul: estudo retrospectivo de 1978-2005. Pesq. Vet. Bras. 26(4):237-242. <http://dx.doi.org/10.1590/S0100736X2006000400008>

Assis-Brasil N.D., Marcolongo-Pereira C., Hinnah F.L., Ladeira S.R.L., Sallis E.S.V., Grecco F.B. \& Schild A.L. 2013. Enfermidades diagnosticadas em bezerros na região sul do Rio Grande do Sul. Pesq. Vet. Bras. 33(4):423-430. <http://dx.doi.org/10.1590/S0100-736X2013000400002>

Bacha F.B., Faccin T.C., Lima S.C., Leal C.R.B. \& Lemos R.A.A. 2014. Dermatofilose em bezerros da raça Nelore no Mato Grosso do Sul. Semina, Ciênc. Agrárias 35(4):1947-1954

Barros C.S.L. \& Figueiredo G.H. 2003. Procedimentos para o diagnóstico das doenças do sistema nervoso central de bovinos. Departamento de Defesa Agropecuária, Ministério da Agricultura, Pecuária e Abastecimento, Brasília, 50p.

Bassuino D.M., Konradt G., Cruz R.A.S., Silva G.S., Gomes D.C., Pavarini S.P. \& Driemeier D. 2016. Characterization of spinal cord lesions in cattle and horses with rabies. J. Vet. Diagnost. Invest. 28(4):455-460. <http://dx.doi. org $/ 10.1177 / 1040638716647992><$ PMid:27240569>

Bingham J. \& Van der Merwe M. 2002. Distribution of rabies antigen in infected brain material: determining the reliability of different regions of the brain for the rabies fluorescent antibody test. J. Virol. Methods 101(1/2):85-94. <http://dx.doi.org/10.1016/S0166-0934(01)00423-2><PMid:11849687>

Blume G.R., Silva L.F., Borges J.R.J., Nakazato L., Terra J.P., Rabelo R.E., Vulcani V.A.S. \& Sant’Ana F.J.F. 2018. Caracterização etiológica, epidemiológica e clínico-patológica da meningoencefalite por herpesvírus bovino em bovinos no Estado de Goiás. Pesq. Vet. Bras. 38(5):902-912.<http://dx.doi. org/10.1590/1678-5150-pvb-5341>

Brum K.B., Purisco E., Lemos R.A.A. \& Riet-Correa F. 2002. Intoxicação por Vernonia rubricaulis em bovinos no Mato Grosso do Sul. Pesq. Vet. Bras. 22(3):119-128. <http://dx.doi.org/10.1590/S0100-736X2002000300006>

Cagnini D.Q., Andrade D.G.A., Cunha P.H.J., Oliveira-Filho J.P., Amorim R.L., Alfieri A.A. \& Borges A.S. 2017. Retrospective study of bovine herpesvirus 5 meningoencephalitis in cattle from São Paulo State, Brazil. Arq. Bras. Med. Vet.Zootec. 69(2):299-304. <http://dx.doi.org/10.1590/1678-4162-9190>

Carvalho A.Q.D., Carvalho N.M., Vieira G.P., Santos A.C.D., Franco G.L., Pott A., Barros C.S.L. \& Lemos R.A.A. 2014. Intoxicação espontânea por Senna obtusifolia em bovinos no Pantanal Sul-Mato-Grossense. Pesq. Vet. Bras. 34(2):147-152. <http://dx.doi.org/10.1590/S0100-736X2014000200009>
Carvalho N.M., Alonso L.A., Cunha T.G., Ravedutti J., Barros C.S.L. \& Lemos R.A.A. 2006. Intoxicação de bovinos por Tetrapterys multiglandulosa (Malpighiaceae) em Mato Grosso do Sul. Pesq. Vet. Bras. 26(3):139-146. <http://dx.doi.org/10.1590/S0100-736X2006000300002>

Carvalho N.M., Bacha F.B., Santos A.C., Carvalho A.Q., Faccin T.C., Pott A. \& Lemos R.A.A. 2013. Spontaneous and experimental intoxication of cattle by Simarouba versicolor A. St.-Hill (Simaroubaceae). Toxicon 64:55-59. <http://dx.doi.org/10.1016/j.toxicon.2012.12.021> <PMid:23319076>

Colodel E.M., Nakazato L., Weiblen R., Mello R.M., Silva R.R.P.D., Souza M.D.A., Filho J.A.D.O. \& Caron L. 2002. Meningoencefalite necrosante em bovinos causada por herpesvírus bovino no estado de mato grosso, Brasil. Ciência Rural 32(2):293-298. <http://dx.doi.org/10.1590/S010384782002000200018>

Dognani R., Pierre E.J., Silva M.D.C.P., Patrício M.A.C., Costa S.C.D., Prado J.R.D. \& Lisbôa J.A.N. 2016. Epidemiologia descritiva da raiva dos herbívoros notificados no estado do Paraná entre 1977 e 2012. Pesq. Vet. Bras. 36(12):1145-1154 <http://dx.doi.org/10.1590/s0100-736x2016001200001>

Dore V. \& Smith G. 2017. Cerebral disorders of calves. Vet. Clin. N. Am., Food Anim. Pract. 33(1):27-41. <http://dx.doi.org/10.1016/j.cvfa.2016.09.004> <PMid:27939221>

Elias F., Schild A.L. \& Riet-Correa F. 2004. Meningoencefalite e encefalomalacia por Herpesvírus bovino-5: distribuição das lesões no sistema nervoso central de bovinos naturalmente infectados. Pesq. Vet. Bras. 24(3):123-131. <http://dx.doi.org/10.1590/S0100-736X2004000300003>

Faccin T.C., Kommers G.D., Galiza G.J.N.D., Pupin R.C., Madureira R.C. \& Lemos R.A.A.D. 2016. Chronic liver disease in cattle associated with ingestion of Brachiaria spp. Ciência Rural 46(11):2036-2042. <http://dx.doi. org/10.1590/0103-8478cr20160297>

Farias N.A. 2007. Tristeza parasitária bovina, p.524-532. In: Riet-Correa F., Schild A.L., Lemos R.A.A. \& Borges J.R.J. (Eds), Doenças de Ruminantes e Equídeos. $3^{\underline{a}}$ ed. Pallotti, Santa Maria.

Fecteau G. \& George L.W. 2004. Bacterial meningitis and encephalitis in ruminants. Vet. Clin. N. Am., Food Anim. Pract. 20(2):363-377. <http:// dx.doi.org/10.1016/j.cvfa.2004.03.002 ><PMid:15203230>

Ferreira L.C.L., Flores E.F., Driemeier D., Melo O. \& Lemos R.A.A. 2008. Doença das mucosas associada à dermatite generalizada em bovinos, Mato Grosso do Sul. Pesq. Vet. Bras. 28(6):285-292. <http://dx.doi.org/10.1590/S0100736X2008000600005>

Galiza G.J.N., Silva M.L.C.R., Dantas A.F.M., Simões S.V.D. \& Riet-Correa F. 2010. Doenças do sistema nervoso de bovinos no semiárido nordestino. Pesq. Vet. Bras. 30(3):267-276. <http://dx.doi.org/10.1590/S0100736X2010000300014>

Guizelini C.C., Lemos R.A.A., de Paula J.L.P., Pupin R.C., Gomes D.C., Barros C.S.L., Neves D.A., Alcântara L.O.B., Silva R.O.S., Lobato F.C.F. \& Martins T.B. 2019. Type $C$ botulism outbreak in feedlot cattle fed contaminated corn silage. Anaerobe 55:103-106. <http://dx.doi.org/10.1016/j.anaerobe.2018.11.003> <PMid:30408576>

Halfen D.C. \& Riet-Correa F. 2007. Infecções por herpesvírus bovino-1 e herpesvírus bovino-5, p.126-137. In: Riet-Correa F., Schild A.L., Lemos R.A.A. \& Borges J.R.J. (Eds), Doenças de Ruminantes e Equídeos. $3^{a}$ ed. Pallotti, Santa Maria.

Heckler R.F., Lemos R.A.A.D., Gomes D.C., Dutra I.S., Silva R.O.S., Lobato F.C.F., Ramos C.A.N. \& Brumatti R.C. 2018. Blackleg in cattle in the state Mato Grosso do Sul, Brazil: 59 cases. Pesq. Vet. Bras. 38(1):6-14.<http://dx.doi. org/10.1590/1678-5150-pvb-4964>

Jonsson N.N., Bock R.E. \& Jorgensen W.K. 2008. Productivity and health effects of anaplasmosis and babesiosis on Bos indicus cattle and their crosses, and the effects of differing intensity of tick control in Australia. Vet. Parasitol. 155(1/2):1-9.<http://dx.doi.org/10.1016/j.vetpar.2008.03.022> <PMid:18472219> 
Lemos R.A.A. 2005. Enfermidades do sistema nervoso de bovinos de corte das regiões Centro-Oeste e Sudeste do Brasil. Doctoral Dissertation, Universidade Estadual Paulista Júlio de Mesquita Filho, Campus Jaboticabal, São Paulo. 149p.

Lemos R.A.A.D., Rech R.R., Guimarães E.B., Kadri A. \& Dutra I.D.S. 2005. Febre catarral maligna em bovinos do Mato Grosso do Sul e de São Paulo. Ciência Rural 35(4):932-934. <http://dx.doi.org/10.1590/S010384782005000400030>

Lima E.F., Riet-Correa F., Castro R.S.D., Gomes A.A.B. \& Lima F.D.S. 2005. Sinais clínicos, distribuição das lesões no sistema nervoso e epidemiologia da raiva em herbívoros na região Nordeste do Brasil. Pesq. Vet. Bras. 25(4):250-264. <http://dx.doi.org/10.1590/S0100-736X2005000400011>

Lucena R.B., Pierezan F., Kommers G.D., Irigoyen L.F., Fighera R.A. \& Barros C.S.L. 2010. Doenças de bovinos no Sul do Brasil: 6.706 casos. Pesq. Vet. Bras. 30(5):428-434. <http://dx.doi.org/10.1590/S0100-736X2010000500010>

Lucena R.B., Rissi D.R., Kommers G.D., Pierezan F., Oliveira-Filho J.C., Macêdo J.T.S.A., Flores M.M. \& Barros C.S.L. 2011. A retrospective study of 586 tumours in Brazilian cattle. J. Comp. Pathol. 145(1):20-24.<http://dx.doi. org/10.1016/j.jcpa.2010.11.002> <PMid:21247583>

Marcolongo-Pereira C., Sallis E.S.V., Grecco F.B., Raffi M.B., Soares M.P. \& Schild A.L. 2011. Raiva em bovinos na Região Sul do Rio Grande do Sul: epidemiologia e diagnóstico imuno-histoquímico. Pesq. Vet. Bras. 31(4):331335. <http://dx.doi.org/10.1590/S0100-736X2011000400010>

Marin M.S., Leunda M.R., Verna A.E., Morán P.E., Odeón A.C. \& Pérez S.E. 2015. Distribution of bovine herpesvirus type 1 in the nervous system os experimentally infected calved. Vet. J. 209:82-86. <http://dx.doi. org/10.1016/j.tvjl.2015.10.034><PMid:26831158>

Mello A.K.M., Brumatti R.C., Neves D.A., Alcântara L.O.B., Araújo F.S., Gaspar A.O. \& Lemos R.A.A. 2019. Bovine rabies: economic loss and its mitigation through antirabies vaccination. Pesq. Vet. Bras. 39(3):179-185. <http:// dx.doi.org/10.1590/1678-5150-pvb-6201>

Mello L.S.D., Bianchi M.V., Bandinelli M.B., Sonne L., Driemeier D. \& Pavarini S.P. 2017. Causas de morte em vacas leiteiras no Rio Grande do Sul. Pesq. Vet. Bras. 37(9):916-920. <http://dx.doi.org/10.1590/s0100736x2017000900003>

Middleton J.R. 2017. Cerebral disorders of the adult ruminant. Vet. Clin. N. Am., Food Anim. Pract. 33(1):43-57. <http://dx.doi.org/10.1016/j. cvfa.2016.09.005><PMid:27956342>

Nakazato L., Lemos R.A.A. \& Riet-Correa F. 2000. Polioencefalomalacia em bovinos nos estados de Mato Grosso do Sul e São Paulo. Pesq. Vet. Bras. 20(3):119-125. <http://dx.doi.org/10.1590/S0100-736X2000000300006>

Oliveira T.S., Bull V., Rezende C.A., Furtini R., Costa É.A., Paixão T.A. \& Santos R.L. 2012. Perfil das amostras do sistema nervoso central de bovinos com síndrome neurológica e diagnóstico da raiva bovina no serviço de defesa sanitária de Minas Gerais, 2003-2010. Pesq. Vet. Bras. 32(4):333-339. <http://dx.doi.org/10.1590/S0100-736X2012000400010>

Paiva F., Lemos R.A.A., Nakazato L., Mori A.E., Brum K.B. \& Bernardo K. 2000. Trypanosoma vivax em bovinos no Pantanal do estado do Mato Grosso do Sul, Brasil: I - Acompanhamento clínico, laboratorial e anatomopatológico de rebanhos infectados. Revta Bras. Parasitol. Vet. 9(2):135-141.

Peixoto P.V. \& Barros C.S.L. 1998. A importância da necropsia em medicina veterinária. Pesq. Vet. Bras. 18(3/4):132-134.<http://dx.doi.org/10.1590/ S0100-736X1998000300008>

Pinto A.P., Santos B.S., Ribas N.L.K.S., Bacha F.B., Carvalho N.M., Driemeier D., Antoniassi N.A.B. \& Lemos R.A.A. 2013. Nonsuppurative myocarditis associated with bovine viral diarrhea vírus infection in calves in the state of Mato Grosso do Sul, Brazil. Acta Scient. Vet. 41(1):1113.

Pupin R.C., Guizelini C.D.C., Lemos R.A.A.D., Martins T.B., Borges F.D.A., Borges D.G.L. \& Gomes D.C. 2019. Retrospective study of epidemiological, clinical and pathological findings of bovine babesiosis in Mato Grosso do Sul,
Brazil (1995-2017). Ticks Tick Borne Dis. 10(1):36-42. <http://dx.doi. org/10.1016/j.ttbdis.2018.08.015><PMid:30196016>

Rech R.R., Rissi D.R., Silva M.C., Inkelmann M.A. \& Barros C.S.L. 2006. Histomorfologia do gânglio de Gasser, da rete mirabile carotídea e da hipófise de bovinos: estudo de 199 casos. Pesq. Vet. Bras. 26(2):105-111. <http://dx.doi.org/10.1590/S0100-736X2006000200008>

Reis M.D.O., Slaviero M., Lorenzett M.P., Cruz R.A.S., Guimarães L.L.B., Pavarini S.P., Driemeier D. \& Sonne L. 2017. Neoplasmas bovinos diagnosticados no setor de Patologia Veterinária da UFRGS, Porto Alegre (2005-2014). Pesq. Vet. Bras. 37(2):105-109. <http://dx.doi.org/10.1590/s0100$736 \times 2017000200002>$

Ribas N.L.K.D.S., Carvalho R.I., Santos A.C.D., Valençoela R.A., Gouveia A.F., Castro M.B.D., Mori A.E. \& Lemos R.A.A.D. 2013. Doenças do sistema nervoso de bovinos no Mato Grosso do Sul: 1082 casos. Pesq. Vet. Bras. 33(10):11831194. <http://dx.doi.org/10.1590/S0100-736X2013001000003>

Rissi D.R. \& Barros C.S.L. 2013. Necrotizing meningoencephalitis in a cow. Vet. Pathol.50(5):926-929. <http://dx.doi.org/10.1177/0300985813478209> <PMid:23446433>

Rissi D.R., Rech R.R., Flores E.F., Kommers G.D. \& Barros C.S.L. 2007. Meningoencefalite por herpesvírus bovino-5. Pesq. Vet. Bras. 27(7):251260. <http://dx.doi.org/10.1590/S0100-736X2007000700001>

Rissi D.R., Pierezan F., Silva M.S., Flores E.F. \& Barros C.S.L. 2008. Neurological disease in cattle in southern Brazil associated with bovine herpesvirus infection. J. Vet. Diagn. Invest. 20(3):346-349. <http://dx.doi. org/10.1177/104063870802000315><PMid:18460624>

Rissi D.R., Pierezan F., Oliveira-Filho J.C., Lucena R.B., Carmo P.M.S. \& Barros C.S.L. 2010. Abordagem diagnóstica das principais doenças do sistema nervoso de ruminantes e equinos no Brasil. Pesq. Vet. Bras. 30(11):958967. <http://dx.doi.org/10.1590/S0100-736X2010001100010>

Roels S., Charlier G., Letellier C., Meyer G., Schynts F., Kerkhofs P., Thiry E. \& Vanopdenbosch E 2000. Natural case of bovine herpesvirus 1 meningoencephalitis in an adult cow. Vet. Rec. 146(20):586-588. <http:// dx.doi.org/10.1136/vr.146.20.586><PMid:10839237>

Rondelli L.A.S., Silva G.S., Bezerra K.S., Rondelli A.L.H., Lima S.R., Furlan F.H., Pescador C.A. \& Colodel E.M. 2017. Doenças de bovinos em Mato Grosso diagnosticadas no Laboratório de Patologia Veterinária da UFMT (2005-2014). Pesq. Vet. Bras. 37(5):432-440.<http://dx.doi.org/10.1590/ s0100-736x2017000500002>

Salvador S.C., Lemos R.A.A., Riet-Correa F., Roehe P.M. \& Osório A.L.A.R. 1998. Meningoencefalite em bovinos causada por herpesvírus bovino-5 no Mato Grosso do Sul e São Paulo. Pesq. Vet. Bras. 18(2):76-83. <http://dx.doi. org/10.1590/S0100-736X1998000200007>

Santos B.L., Estima-Silva P., Coelho A.C.B., Oliveira P.A., Soares M.P., Sallis E.S.V., Bruhn F.R.P. \& Schild A.L. 2018. Doenças do sistema nervoso central de bezerros no sul do Rio Grande do Sul: uma contribuição ao diagnóstico diferencial. Pesq. Vet. Bras. 38(4):685-691. <http://dx.doi. org/10.1590/1678-5150-pvb-5360>

Santos B.L., Ladeira S.R.L., Riet-Correa F., Soares M.P., Marcolongo-Pereira C., Sallis E.S.V., Raffi M.B. \& Schild A.L. 2019. Clostridial diseases diagnosed in cattle from the South of Rio Grande do Sul, Brazil. A forty-year survey (1978-2018) and a brief review of the literature. Pesq. Vet. Bras. 39(7):435446. <http://dx.doi.org/10.1590/1678-5150-pvb-6333>

Santos B.S., Pinto A.P., Aniz A.C.M., Almeida A.P.M.G.D., Franco G.L., Guimarães E.B. \& Lemos R.A.A. 2012. Mortalidade de bovinos zebuínos por hipotermia em Mato Grosso do Sul. Pesq. Vet. Bras. 32(3):204-210. <http://dx.doi. org/10.1590/S0100-736X2012000300004>

Schild A.L., Pereira C.M., Fiss L., Santos B.L., Coelho A.C.B. \& Sallis E.S.V. 2013. Doenças diagnosticadas pelo laboratório regional de diagnóstico no ano 2012, p.35-64. In: Ladeira S.R.L., Ruas J.L., Soares M.P. \& Schild A.L. (Eds), Boletim do Laboratório Regional de Diagnóstico. Universidade Federal de Pelotas, Pelotas.

Schulz L.L., Hayes D.J., Holtkamp D.J. \& Swenson D.A. 2018. Economic impact of university veterinary diagnostic laboratories: a case study. Prev. Vet. 
Med. 151:5-12. <http://dx.doi.org/10.1016/j.prevetmed.2017.12.018> $<$ PMid:29496106>

Soares M.C., Gaspar A.O., Brumatti R.C., Gomes D.C., Neves D.A., Alcântara L.O.B., Leal P.V. \& Lemos R.A.A. 2018a. Economic impact of an outbreak of botulism in a cattle feedlot. Pesq. Vet. Bras. 38(7):1365-1370. <http:// dx.doi.org/10.1590/1678-5150-pvb-5643>

Soares M.C., Pupin R.C., Guizelini C.C., Gaspar A.O., Gomes D.C., Brumatti R.C. \& Lemos R.A.A. 2018b. Economic losses due to Vernonia rubricaulis poisoning in cattle. Pesq. Vet. Bras. 38(12):2217-2223. <http://dx.doi. org/10.1590/1678-5150-pvb-6075>

Souza R.I.C., Santos A.C.D., Ribas N.L.K.D.S., Colodel E.M., Leal P.V., Pupin R.C., Carvalho N.M. \& Lemos R.A.A.D. 2015. Doenças tóxicas de bovinos em Mato Grosso do Sul. Semina, Ciênc. Agrárias 36(3):1355-1368. <http://dx.doi. org/10.5433/1679-0359.2015v36n3p1355>
Svensson C., Linder A. \& Olsson S.O. 2006. Mortality in Swedish dairy calves and replacement heifers. J. Dairy Sci. 89(12):4769-4777. <http://dx.doi. org/10.3168/jds.S0022-0302(06)72526-7> <PMid:17106108>

Terra J.P., Blume G.R., Rabelo R.E., Medeiros J.T., Rocha C.G.N., Chagas I.N., Aguiar M.D.S. \& Sant'Ana F.J.F.D. 2018. Neurological diseases of cattle in the state of Goiás, Brazil (2010-2017). Pesq. Vet. Bras. 38(9):1752-1760. <http://dx.doi.org/10.1590/1678-5150-pvb-5768>

Waldner C.L., Kennedy R.I., Rosengren L. \& Clark E.G. 2009. A field study of culling and mortality in beef cows from western Canada. Can. Vet. J. 50(5):491-499. <PMid:19436634>

Watson E.N., David G.P. \& Cook A.J.C. 2008. Review of diagnostic laboratory submissions of adult cattle 'found dead' in England and Wales in 2004. Vet. Rec. 163(18):531-535. <http://dx.doi.org/10.1136/vr.163.18.531> <PMid:18978365> 